J. Clin. Chem. Clin. Biochem.

Vol. 17, 1979, pp. 731-737

\title{
Atypical Serum Creatine Kinase Isoenzyme Pattern Caused by Complexing of Creatine Kinase-BB with Immunoglobulins $G$ and $A^{1}$ ), ${ }^{2}$ )
}

\author{
By Evangelia Jockers-Wretou and Elisabeth Plessing \\ Institut fưr Organische Chemie, Biochemie und Isotopenforschung der Universität Stuttgart
}

(Received June 21/August 1, 1979)

In commemoration of Professor Dr. Gábor Szász

Summary: 12 cases are described, which show high serum creatine kinase-BB levels, as well as atypical creatine kinase activity band located between normally migrating creatine kinase-MM and creatine kinase-MB. It is shown that the altered properties of the serum creatine kinase-BB, namely its molecular size, heat resistance, electrophoretic mobility, but not its immunological behavior, are caused by complexing with kappa-chains of immunoglobulins $\mathrm{G}$ or $\mathrm{A}$. The complex occurring in vivo could also be produced in vitro by using purified patients' IgG and human creatine kinaseBB.

The interaction of creatine kinase-BB with immunoglobulins possibly protects the enzyme against intravascular degradation in vivo, and may therefore account for the high creatine kinase-BB levels observed in these patients.

\section{Atypisches Isoenzymmuster von Kreatinkinase im Serum infolge Komplexbildung von Kreatinkinase-BB mit Immun- globulin $G$ und $A$}

Zusammenfassung: Es werden 12 Fälle beschrieben, die eine erhöhte Kreatinkinase-BB-Aktivität im Serum als auch eine atypische Kreatinkinase-Bande zwischen Kreatinkinase-MM und Kreatinkinase-MB aufweisen. Es wird gezeigt, daß die veränderten Eigenschaften der Serum-Kreatinkinase-BB, nämlich Molekulargewicht, Hitzestabilität, elektrophoretische Mobilität, aber nicht das immunologische Verhalten, auf die Bindung des Enzyms an kappa-Ketten der Immunoglobuline $G$ und $A$ zurückzuführen sind. Der in vivo auftretende Komplex konnte auch in vitro reproduziert werden und zwar mit gereinigtem Patienten-IgG und humaner Kreatinkinase-BB.

Die Bindung zwischen Kreatinkinase-BB und Immunoglobulinen schützt möglicherweise das Enzym in vivo gegen intravasale Degradation und könnte somit die bei diesen Patienten auftretende erhöhte Kreatinkinase-BB-Aktivität hervorrufen.

\section{Introduction}

Occurrence of the creatine kinase (EC 2.7.3.2) isoenzyme $\mathrm{BB}$ (creatine kinase- $\mathrm{B} \overline{\mathrm{B}}$ ) in patient sera without correlation to any specific disease has recently been reported $(1,2)$. It was designated as "idiopathic creatine kinase-BB" (1), or as a "variant creatine kinase isoenzyme" (2). The reported cases had three properties in common, namely

1. an atypical creatine kinase activity band located between normally migrating creatine kinase-MM and creatine kinäse-MB,

1) Supported by the Deutsche Forschungsgemeinschaft

2) Presented in part at the 3 rd European Congress of Clinical Chemistry, Brighton, 1979
2. unusually high concentrations of creatine kinase-BB and

3. prolonged appearance of creatine kinase-BB in the serum.

The present report was initiated by the hypothesis that the above mentioned properties of creatine kinase-BB could be due to interaction of the enzyme with a serum factor. The results of 12 cases showing atypical isoenzyme pattern as well as high creatine kinase-BB levels in the serum are described.

\section{Material and Methods}

Patients' sera: The reported cases were detected in several hospitals by their abnormally high creatine kinase-MB activities with the immunoinhibition test (Merck). Serum samples 
were generously left at the authors' disposal for further characterization. The samples were stored without any thiol at $-25^{\circ} \mathrm{C}$ until use. During the experiments they were kept at $4{ }^{\circ} \mathrm{C}$ after addition of 2 -mercaptoethanol (final concentration $20 \mathrm{mmol} / \mathrm{l})$.

Enzyme assay: Creatine kinase activity measurements were made at $25^{\circ} \mathrm{C}$ by the Rosalki-Oliver method (3) using the kit "CK-NAC-activated" (Boehringer, Mannheim). The reaction was monitored with an Eppendorf photometer at $365 \mathrm{~nm}$.

Creatine kinase isoenzyme measurements were done by the immunotitration assay developed in this laboratory and modified as reported previously $(4,5)$, using purified IgG from sheep antisera against human creatine kinase-MM and creatine kinase-BB (Merck, Darmstadt). Creatine kinase-BB activity in column eluates was assayed by the immunoinhibition test "CK-MB, NAC activated" (Merck). The results were not multiplied by two (6).

Electrophoresis was performed at $4{ }^{\circ} \mathrm{C}$ on cellulose acetate strips (Macherey \& Nagel, Düren) in $30 \mathrm{mmol} / 1$ Veronal buffer, $\mathrm{pH} 8.6$ at $200 \mathrm{~V}$ for one hour. Creatine kinase activity bands were visualized by overlaying the membranes with an agarose-substrate mix ture and incubating for $30-60 \mathrm{~min}$ at $37^{\circ} \mathrm{C}$. The strips were dried, viewed in UV-light and finally stained with Coomassie Brillant Blue G 250 (Serva, Heidelberg) $(2.5 \mathrm{~g} / 1$ in methanol: water: acetic acid, volumes $5+5+1$ ). Isoelectric focussing studies were performed on Ampholine PAG-plates (LKB, Karlsruhe), $\mathrm{pH}$ 3.5-9.5, with a Desaga apparatus, for 1.5 hour. After washing in distilled water for $15 \mathrm{~min}$ the polyacrylamide gelplates were stained for creatine kinase activity as described above.

Creatine kinase isoenzymes: Crystalline creatine kinase-MM from human muscle was purified as reported previously (4). Human brain obtained at autopsy was used as source of creatine kinase-BB. Extracts were made in Tris/ $\mathrm{HCl}$ buffer pH $8.0(50 \mathrm{mmol} / 1,1 \mathrm{mmol} / 1 \mathrm{EDTA}, 10 \mathrm{mmol} / 1 \mathrm{KCl}, 20 \mathrm{mmol} / 1$ 2-mercaptoethanol). The enzyme was partly purified by $\left(\mathrm{NH}_{4}\right)_{2}$ $\mathrm{SO}_{4}$-fractionation and chromatography on Sephadex-G-200 (Pharmacia, Sweden). Hybridization of creatine kinase-MM and creatine kinase-BB was performed in $6 \mathrm{~mol} / \mathrm{l}$ urea. After dialysis against Tris-buffer $\mathrm{pH} 8.0(50 \mathrm{mmol} / 1,1 \mathrm{mmol} / 1 \mathrm{EDTA}$, $20 \mathrm{mmol} / 1$ 2-mercaptoethanol) the relative isoenzyme concentrations were estimated immunologically. The isoenzyme mixture was diluted in normal heat-inactivated serum (serum matrix) and used as a control for the electrophoretic runs.
Purification of immunoglobulins: Immunoglobulins G, M and A were estimated by single radial immunodiffusion on agar plates (Tri-Partigen, Behringwerke, Marburg). Immunoglobulins G were purified from the patients' sera on a Protein A-Sepharose CL-4B column (Pharmacia), using an acid eluent $(0.1 \mathrm{~mol} / 1$ glycine $/ \mathrm{HCl}, \mathrm{pH} 3.0$ ) (7). The eluate was immediately neutralized and concentrated through selectron ultramembranes (Schleicher \& Schüll; Dassel). The concentration of the purified IgG was estimated by its absorbance at $280 \mathrm{~nm}$, taking A $\frac{1 \%}{280}=14.6(8)$.

Immunological techniques: Double diffusion, immunoelectrophoresis and two dimensional "rocket" immunoelectrophoresis were carried out on agarose gels $(8 \mathrm{~g} / \mathrm{l})$ according to the corresponding techniques by Ouchterlony (9), Grabar (10) and Laurell (11). The agarose plates were washed twice in $9 \mathrm{~g} / 1 \mathrm{NaCl}$ and stained for creatine kinase activity as described for the electropherograms. Control sera and antisera against human plasma proteins were purchased from Behringwerke.

\section{Results}

Age, sex, diagnosis and creatine kinase isoenzyme serum activities of the reported cases are summarized in table 1. Creatine kinase serum activity varied from 32 to 349 $\mathrm{U} / \mathrm{l}$ and the relative creatine kinase-BB was $10-95 \%$ (16-300 U/1). Serum protein electrophoresis was without any particularities. Concentrations of immunoglobulins $\mathrm{G}, \mathrm{A}$ and $\mathrm{M}$ were within normal ranges.

\section{Stability}

The serum creatine kinase activity was stable for several days at $25^{\circ} \mathrm{C}$ and for at least two months at $4{ }^{\circ} \mathrm{C}$. A remarkable stability was further observed at $37^{\circ} \mathrm{C}$ as shown in figure $1 \alpha$ for case no. 11 . In contrast, incubation of human creatine kinase-BB in serum matrix resulted in approximately $80 \%$ loss of the activity within one hour (fig. $1 \beta)$.

Tab. 1. Diagnosis, age, sex and serum creatine kinase (CK) isoenzyme activities of the patients.

\begin{tabular}{|c|c|c|c|c|c|c|c|}
\hline $\begin{array}{l}\text { Case } \\
\text { no. }\end{array}$ & Age & Sex & $\begin{array}{l}\text { CK activity } \\
(\mathrm{U} / 1)\end{array}$ & $\begin{array}{l}\text { CK-MM } \\
(\%)\end{array}$ & $\begin{array}{l}\text { CK-MB } \\
(\%)\end{array}$ & $\begin{array}{l}\text { CK-BB } \\
(\%)\end{array}$ & Diagnosis \\
\hline $\begin{array}{l}1 \\
2 \\
3 \\
4 * * * \\
5 \\
6 \\
7 \\
8 \\
9 \\
10 \\
11 \\
12 \text { a) } \\
\text { b) } \\
\text { c) }\end{array}$ & $\begin{array}{l}81 \\
60 \\
60 \\
68 \\
65 \\
28 \\
78 \\
64 \\
50 \\
55 \\
47 \\
71\end{array}$ & $\begin{array}{l}9 \\
8 \\
9 \\
0 \\
0 \\
9 \\
9 \\
9 \\
9 \\
9 \\
0 \\
9 \\
0\end{array}$ & $\begin{array}{r}74 \\
32 \\
87 \\
349 \\
120 \\
112 \\
116 \\
111 \\
73 \\
47 \\
130 \\
266 \\
148 \\
78\end{array}$ & $\begin{array}{r}22 \\
50 \\
36 \\
14 \\
16 \\
22 \\
5 \\
38 \\
70 \\
.52 \\
22 \\
74 \\
85 \\
57\end{array}$ & $\begin{array}{r}11 \\
0 \\
16 \\
0 \\
0 \\
0 \\
0 \\
0 \\
29 \\
5 \\
0 \\
0 \\
16 \\
0 \\
0\end{array}$ & $\begin{array}{l}67 \\
50 \\
48 \\
86 \\
84 \\
78 \\
95 \\
32 \\
25 \\
48 \\
78 \\
10 \\
15 \\
22\end{array}$ & $\begin{array}{l}\text { cerebral vasc. insufficiency } \\
\text { cerebral insult* } \\
\text { unknown } \\
\text { rehabilitation after m. infarct } \\
\text { angina pectoris } \\
\text { asthma bronchiale } \\
\text { angina pectoris } \\
\text { m. infarct } \\
\text { m. infarct** } \\
\text { ischemic chest pain } \\
\text { degenerative coronary disease } \\
\text { m. infarct } 1 \text { st**** } \\
\quad 2 \text { nd } \\
3 \text { rd }\end{array}$ \\
\hline
\end{tabular}

\footnotetext{
* 2 weeks after injury

** 4 days after onset

*** Cases no. $4,5,6,7$ and 8 correspond to no. 1,2,4,5 and 6 reported in 1.c. (19)

$* * * *$ days after onset
} 


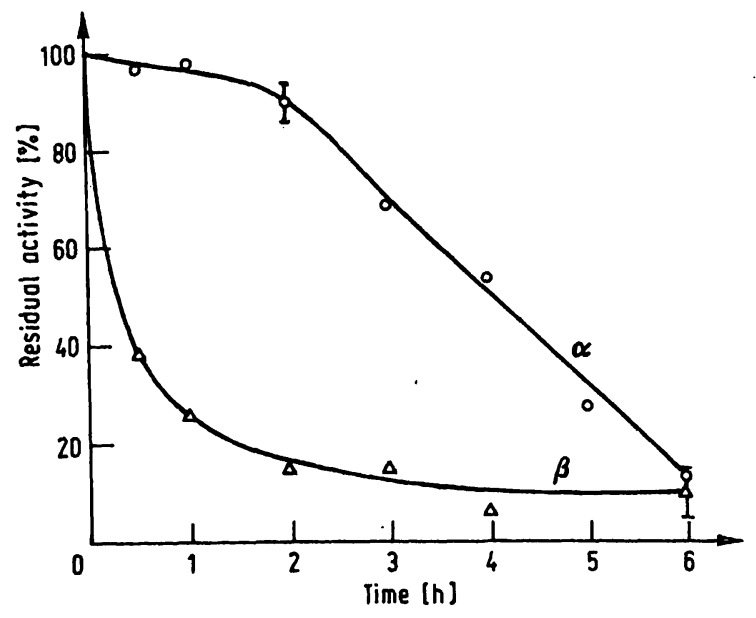

Fig. 1. Thermal stability of creatine kinase activity at $37^{\circ} \mathrm{C}$. $\alpha$ ) serum no. $11, \beta)$ human creatine kinase-BB in serum matrix $(100 \mathrm{U} / 1)$. (Aliquots were sampled for enzyme assay at the times shown). All points are means of three estimations with the representative SD shown.

\section{Immunotitration assay}

The immunotitration curves of serum no. 11 and of native creatine kinase- $\mathrm{BB}$ in a serum matrix against antihuman creatine kinase-BB immunoglobulins are compared in figure 2 . Slope and titration point of both curves are very similar (with respect to the relative creatine kinase-BB in the serum). A slight difference was observed as increasing amounts of antibody resulted in an increase of the residual activity in the patient serum curve.

Electrophoresis: Electrophoretic patterns of some serum samples are shown in figure 3. A single creatine kinase activity band in the $\beta$-globulin region was located between normally migrating creatine kinase-MM and creatine kinase-MB, except for case no. 5. The creatine kinase activity band migrated in this serum very close to the creatine kinase-MB band of the control. The cathodal band corresponding to creatine kinase-MM was observed in some sera ( 9 and 10). In many cases, however, the MM-band was not always detectable as indicated by the

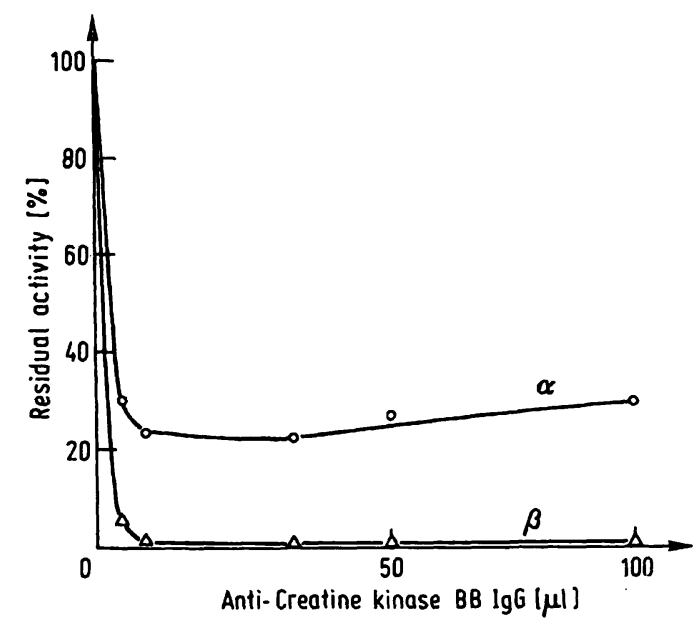

Fig. 2. Immunotitration assay of $\alpha$ ) serum no. 11 creatine kinase activity and $\beta$ ) human creatine kinase-BB in serum matrix Aliquots of the patient's serum $(50 \mathrm{mU})$ and of human creatine kinase-BB in serum matrix $(40 \mathrm{mU})$, both containing $3.5 \%$ polyethyleneglycol, were incubated with sheep IgG against human creatine kinase-BB. Tris buffer, $\mathrm{pH} 8.0$ (0.05 mol$/ 1 ; 1 \mathrm{mmol} / 1 \mathrm{EDTA}, 20 \mathrm{mmol} / 1$ 2-mercap toe thanol) was added to a final volume of $450 \mu$ l. The residual activity is expressed as a percentage of the contrnl after incubation $\left(1 \mathrm{~h} 25^{\circ} \mathrm{C}\right)$ and centrifugation.

dashed lines, or it was even totally undetectable. Case no. 12 (not shown) revealed the atypical band and a normally migrating creatine kinase-MB band as well. Isoelectric focussing studies showed an analogous behavior. Creatine kinase activity bands were located at the position of creatine kinase-MM and between creatine kinase-MM and creatine kinase-MB ( $\mathrm{pH} 5.6-$ 6.8). Furthermore, a strong naturally occurring fluorescent band was seen at $\mathrm{pH} 4.5$, the isoelectric point of normally migrating creatine kinase-BB.

Increasing amounts of native creatine kinase-BB were added to a constant volume of the patients' sera. Subsequently, the samples were analyzed electrophoretically and assayed for creatine kinase activity. A shown in figure 4, the exogenous creatine kinase-BB migrated first to the same position as the atypical band. Further addition of creatine kinase-BB revealed the anodically

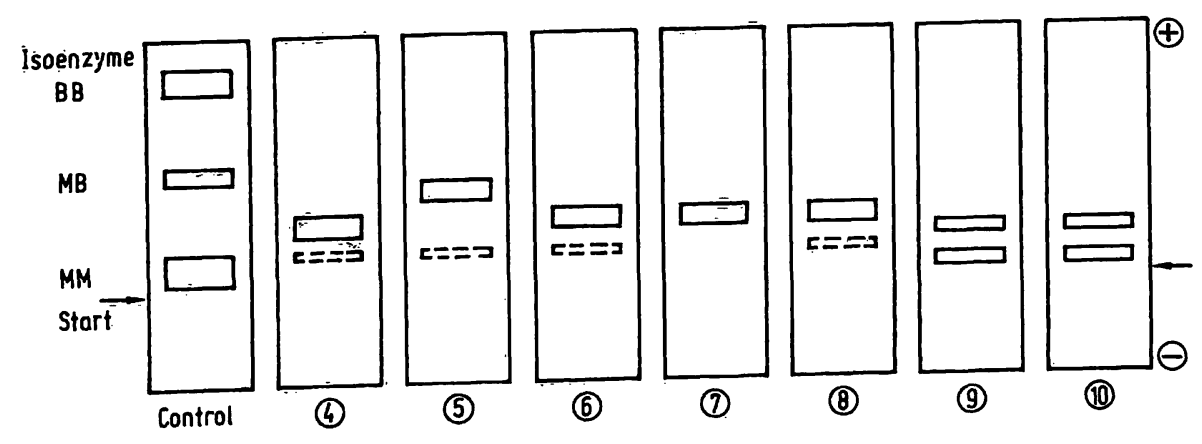

Fig. 3. Electropherograms of creatine kinase isoenzymes in some serum samples. 


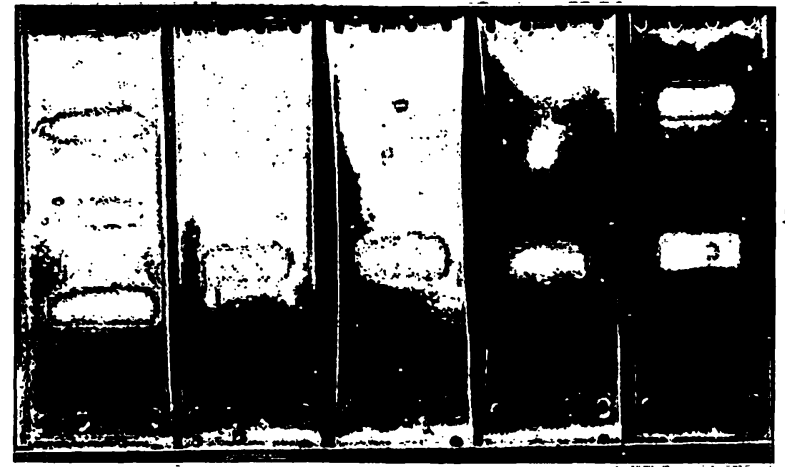

Fig. 4. Electropherogram of serum no. 7 after addition of increasing amounts of human creatine kinase-BB.

Exogenous creatine kinase-BB was added to $100 \mu \mathrm{l}$ serum at the following concentrations. Left to right: control, no. 7, no. 7 with $6 \mathrm{mU}$ creatine kinase-BB, no. 7 with $30 \mathrm{mU}$ creatine kinase-BB, no. 7 with $120 \mathrm{mU}$ creatine kinase-BB.

migrating creatine kinase-BB in addition to the atypical band. The measured creatine kinase activity of the samples was compared with their theoretical activity as calculated by addition of the endogenous and exogenous enzyme activities. This measured activity was $30 \%$ less than the calculated activity in all cases. These results indicated the presence of a serum factor capable of forming a stable creatine kinase-BB complex with a limited creatine kinase-BB activity.

Efforts to precipitate the creatine kinase-BB factor complex with anti-human creatine kinase-BB serum failed. In contrast, exogenous added creatine kinase-BB migrated normally after the patients' sera were treated with antiserum against human plasma proteins. This indicated the factor(s) to be a normal component of human serum.

\section{Column chromatography:}

Two peaks showing creatine kinase activity were obtained after serum no. 11 chromatography on Sephadex G-200 (fig. 5). A small peak (II) corresponding to a molecular mass of 80000 was identified as creatine kinase-MM. A second peak (I) of higher molecular mass (240 000) exhibited only creatine kinase-BB activity.

\section{Immunological studies}

The Laurell technique was used to analyze the eluate from the Sephadex column containing creatine kinaseBB activity, using a polyvalent antiserum against human serum proteins. When stained for creatine kinase activity one of the precipitin peaks showed strong fluorescence. The corresponding serum protein was identified as IgG by specific anti-IgG serum. All patients' sera assayed by this technique demonstrated a fluorescent precipitin peak of $\mathrm{IgG}$, except case no. 5 . In this case the complexing protein was identified as IgA, as shown in figure 6.

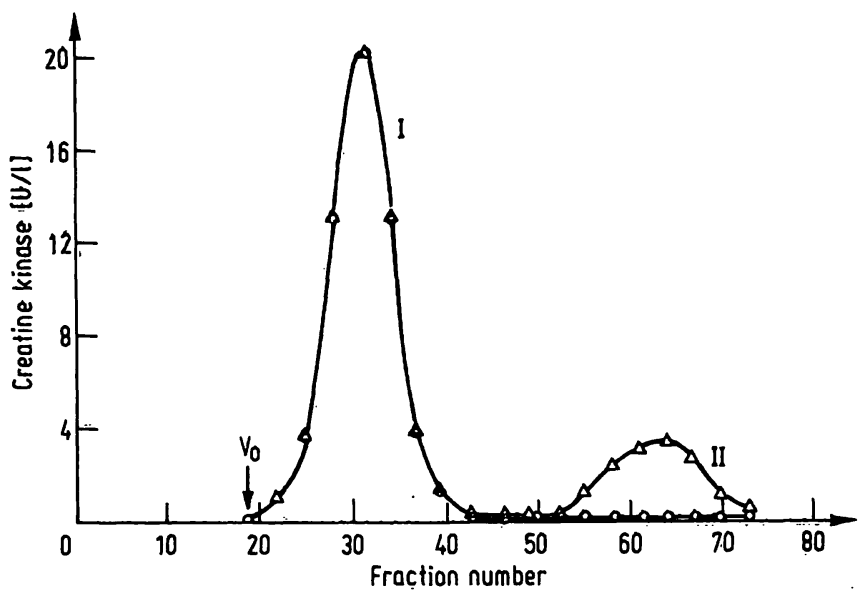

Fig. 5. Elution pattern of serum no. 11 creatine kinase activity from a Sephadex G-200 column. $3 \mathrm{ml}$ serum no. 11 were applied to the column and eluted with Tris buffer $\mathrm{pH} 8.0$ ( $0.05 \mathrm{~mol} / 1,1 \mathrm{mmol} / 1$ EDTA, $20 \mathrm{mmol} / 12$-mercaptoethanol). Fractions were assayed for total creatine kinase activity $(\Delta--\Delta)$ and for creatine kinase-BB activity (O- - - ) using the immunoinhibition assay. Column dimensions: $25 \times 850 \mathrm{~mm}$, void volume: $93 \mathrm{ml}$, fraction volume: $1.6 \mathrm{ml}$.

It is noteworthy that only one side of the peak shows creatine kinase activity. Figure 7 demonstrates the patterns observed in the technique of Grabar for two other cases. Precipitin arcs produced by immunoelectrophoresis of the patients' sera versus specific anti-human- $\kappa$-L-chain serum manifested creatine kinase activity. Filuorescence could not be observed by using anti-human- $\lambda$-L-chain serum.

\section{Complexing in vitro}

Increasing amounts of purified IgG from serum no. 11 were added to a constant concentration of creatine kinase- $\mathrm{BB}$, thus simulating an immunotitration assay. 


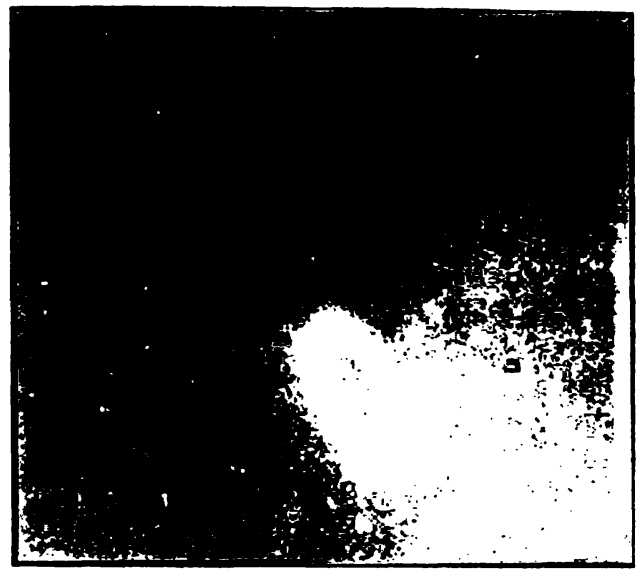

Fig. 6. Laurell-electropherogram stained for creatine kinase activity. Antigen: $15 \mu \mathrm{l}$ of serum no. 5 .

Antiserum: anti-human IgA serum; concentration on the plate $5 \mathrm{ml} / \mathrm{l}$.
Electrophoresis of the samples revealed the "atypical" band of the IgG-creatine kinase-BB complex formed in vitro (fig. 8). The titration point was estimated from the $\mathrm{IgG}$ concentration required to complex all the creatine kinase-BB present; this value was $18.6 \mathrm{U} / \mathrm{g}$ $\operatorname{lgG}$, representing a molecular ratio IgG: creatine kinase$\mathrm{BB}=9000: 1$, assuming $320 \mathrm{U} / \mathrm{mg}$ for the specific activity of pure creatine kinase-BB.

The interaction between creatine kinase- $\mathrm{BB}$ and the purified IgG was further studied using the Ouchterlony technique. As shown in figure 9 the precipitin line between creatine kinase-BB and anti-creatine kinase$B B$ serum was not disturbed by the presence of the patient's IgG.

This result, and the observation that the purified IgG slightly inhibited human creatine kinase-BB as well as creatine kinase-MM, both to the same extent, provided strong evidence for a rather nonspecific protein-protein complex.

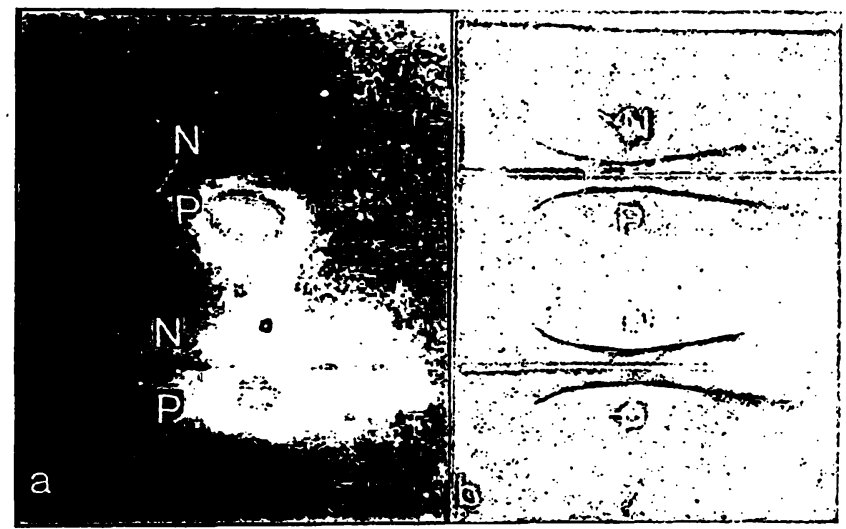

Fig. 7. Immunoelectrophoresis pattern of serum no. 6 (top) and serum no. 8 (bottom) versus monospecific anti-IgG antiserum. $\dot{P}$ : patient serum, $\mathrm{N}$ : control serum.

a) slide stained for creatine kinase activity b) slide stained with Coomassie BB.

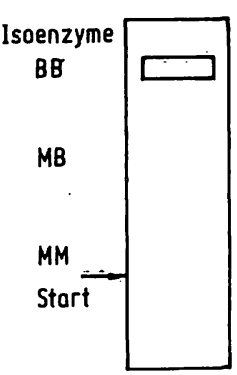

(a)

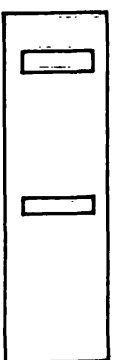

(b)

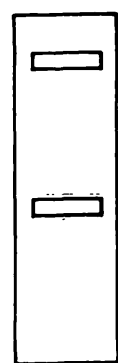

(c)

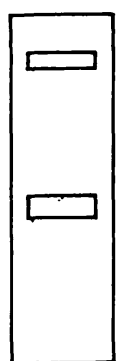

(d)

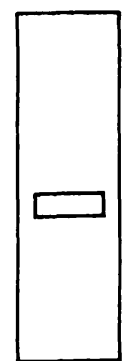

(e)

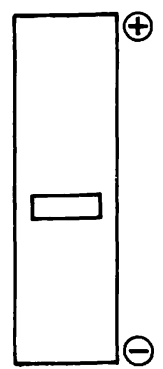

(1)

Fig. 8. Electropherograms.

In vitro interaction of purified patient's IgG with human creatine kinase-B
were added to $35 \mathrm{mU}$ creatine kinase-BB in Tris standard buffer $\mathrm{pH} 8.0$

were added to $35 \mathrm{mU}$ creatine kinase-BB in $\mathrm{T}$

b) with $30 \mu \mathrm{lgG}$

c) with $50 \mu 1 \mathrm{IgG}$

d) with $100 \mu \mathrm{IgG}$

e) with $250 \mu 1 \mathrm{IgG}$

f) with $300 \mu 1 \mathrm{IgG}$

J. Clin: Chem. Clin. Biochem. / Vol. 17, 1979 / No. 11 


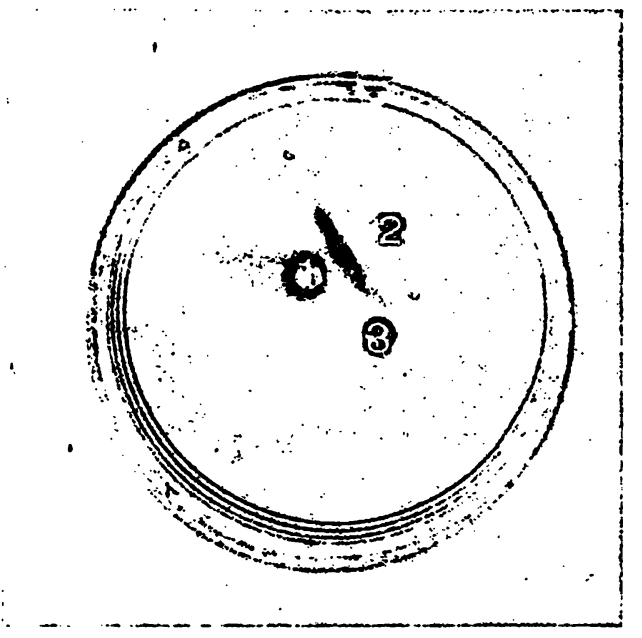

Fig. 9. Double immunodiffusion plate stained for creatine kinase activity.

1: human creatine kinase-BB, 2: purified IgG against creatine kinase-BB, 3: purified IgG of serum no. 11 .

\section{Discussion}

The present results demonstrate that the atypical creatine kinase isoenzyme pattern observed in patients with high creatine kinase-BB levels was due to complexing of creatine kinase-BB with the patients' immunoglobulins. Urdal \& Laudaas have come to similar conclusions by using other techniques (20). In 11 out of 12 cases studied, immunoglobulin $G$ was the complexing factor. In one case creatine kinase-BB was linked to IgA.

The creatine kinase-BB activity in the complex was extremely stable at $25^{\circ} \mathrm{C}, 4{ }^{\circ} \mathrm{C}$ and $37^{\circ} \mathrm{C}$ as compared with the activity of native creatine kinase-BB stored under similar conditions. These results could partly explain the high concentration of creatine kinase-BB and its prolonged appearance in the sera. The immunotitration curve and the formation of the complex between purified IgG and exogenous creatine kinase$\mathrm{BB}$ in vitro both indicated that a normal creatine kinase$\mathrm{BB}$ protein was involved in the complex. On the other hand the patients' immunoglobulins revealed normal precipitin arcs as compared with control serum (fig. 7).

The stoichiometric composition of the complex was estimated to be $1: 1$ from the molecular mass obtained by gel filtration. The complexing capacity (mol IgG: mol creatine kinase-BB) of the purified IgG was found to be $9000: 1$ in the in vitro assay for case no. 11. Thus, one out of 9000 molecules of that patient's IgG is able to bind one molecule creatine kinase-BB. This ratio may, however, vary from case to case. The complexing ability of the immunoglobulins was further restricted to the $k$ L-class.

The assumption of antibody formation against creatine kinase-BB could be excluded on the basis of the results obtained by the immunotitration and the Ouchterlony technique.
Complexing of immunoglobulins with enzymes is a well known phenomenon in the clinical literature. Several reports have described complex formation between IgG and human enzymes, such as aspartate aminotransferase, lactate dehydrogenase and alkaline phosphatase $(12,13,14)$. Binding may even occur between immunoglobulins and plasma proteins (15).

Prabhakaran et al. recently reported the interaction of human IgG with human creatine kinase-BB (16). The described complex, however, is clearly distinct from that reported in this paper, having a higher molecular mass $(825000)$. Moreover, the lability of the high molecular mass complex, discussed by the authors as a possible route for creatine kinase-BB intravascular catabolism, contrasts strongly with the stability of the $1: 1$ complex, discussed as a possible reasore for the prolonged occurrence of creatine kinase-BB in the patients' sera.

Atypical creatine kinase isoenzyme patterns have often been reported. Velletri et al. described creatine kinaseMM linked to $\beta$-lipoprotein and migrating between creatine kinase-MM and creatine kinase-MB (17). A similar mobility characterized the atypical pattern reported by $S a x$ et al. (18).

Previously we reported high creatine kinase-BB levels present during 10 months in the serum of a patient suffering from a nervous system disorder. The data were obtained by immunotitration (5). On the basis of the present results, complexing of creatine kinase-BB with immunoglobulins might also have caused the stability of creatine kinase-BB in that case. The frequency of the "idiopathic" creatine kinase-BB presence in patients' sera has been estimated to be 1:1000 (1) or $1: 100(2)$.

In a recent study we demonstrated that the detection and adequate estimation of the creatine kinase isoenzymes in these atypical sera can only be achieved 
by using immunological methods able to distinguish between creatine kinase-MB and creatine kinase-BB (19). Even the immuno inhibition assay (Merck) can lead to misinterpretation, especially when small amounts of creatine kinase-BB are present and multiplication by 2 results in a "normal" creatine kinase-MB activity.

The main question, as to the tissue of origin of the high creatine kinase-BB serum levels, remains, however, unsolved. Since the nervous system and gastro-intestinal tract are the tissues with the highest creatine kinase-BB concentration, they are both likely to be the source of creatine kinase-BB. On the other hand, only one common denominator could be found, namely the ability of the patients' immunoglobulins to complex creatine kinaseBB.

\section{References}

1. Lang, H., Würzburg, K., Neumaier, D., Knedel, H., Prellwitz, W., Kattermann, R., Schlebusch, H. \& Schürmann, J. (1978), Klin. Wochenschr. 56, 641-646.

2. Ljungdahl, L. \& Gerhardt, W. (1978), Clin. Chem. 24, 832834.

3. Rosalki, S. B. (1967), J. Clin. Lab. Med. 69, 696-705.

4. Jockers-Wretou, E. \& Pfleiderer, G. (1976), Clin. Chim. Acta $73,183-186$.

5. Jockers-Wretou, E., Grabert, K., Müller, E. \& Pfleiderer, G. (1976), Clin. Chim. Acta 73, 183-186.

6. Würzburg, K., Hennrich, N., Lang, H., Prellwitz, W., Neumeier, D. \& Knedel, M. (1976), Klin. Wochenschr. 54, $357-360$.

7. Hjelm, H., Hjelm, K. \& Sjöquist, J. (1972), FEBS Lett. 28, 31.

8. Robbins, J. B. \& Schneerson, R. (1974), Methods in Enzymology 34,725 .

9. Ouchterlony, O., (1948), Acta Pathol. Microbiol. Scand. 25, 186-191.
The thermal stability of the complexed enzyme in vitro reasonably suggests that creatine kinase-BB is protected in a similar way against intravascular degradation in vivo. Serum creatine kinase-BB levels depend thus on the serum concentration of the specific complexing immunoglobulin L-chains and may reflect a normal cell efflux, rather than any particular tissue or membrane damage.

\section{Acknowledgments}

The help of Professor Dr. Dr. H. Wisser, Stuttgart, Professor Dr. H. Lehmann, Marburg, Dr. H. Chemnitz, Hannover and Dr. A. Wilhelm, Münster, in supplying serum specimens is gratefully acknowledged. Quantitative serum protein electrophoreses and estimations of IgG, IgA and IgM were performed at the Dept. of Clinical Chemistry, Robert-Bosch-Krankenhaus, Stuttgart; Head: Professor Wisser.
10. Graber, P.\& Williams, C. A. (1953), Biochim. Biophys. Acta 10, 193.

11. Laurell, C. B. (1965), Anal. Biochem. 10, 358-361.

12. Konntinen, A., Murros, J., Ojala, K. (1978), Clin. Chim. Acta 84, 145.

13. Nagamine, M. (1972), Clin. Chim. Acta 36, 139-144.

14. Nagamine, M. \& Okhuma, S. (1975), Clin. Chim. Acta 65 , 39-46.

15. Laurell, C. B. (1970), Immunochemistry 7, 461-465.

16. Prabhakaran, V., Nealon, D. A. \& Henderson, A. R. (1979), Clin. Chem. 25, 112-116.

17. Velletri, K., Griffiths, W. C. \& Diamond, I. (1975), Clin. Chem. 21, 1837-1838.

18. Sax, S. M., Moore, J. J., Giegel, J. L. \& Welsh, M. (1976) Clin. Chem. 22, 87-91.

19. Chemnitz, G., Jockers-Wretou, E., Schmidt, E., Schmidt, F. W. \& Lobers, J. (1979), J. Clin. Chem. Clin. Biochem. $17,725-729$.

20. Urdal, P. \& Landaas, S. (1979), Clin. Chem. 25, 461-465.
Dr. Evangelia Jockers-Wretou The Hellenic National Research Foundation Biological Research Center 48, Vassileos Konstantinou Avenue GR-508 Athens Greece 

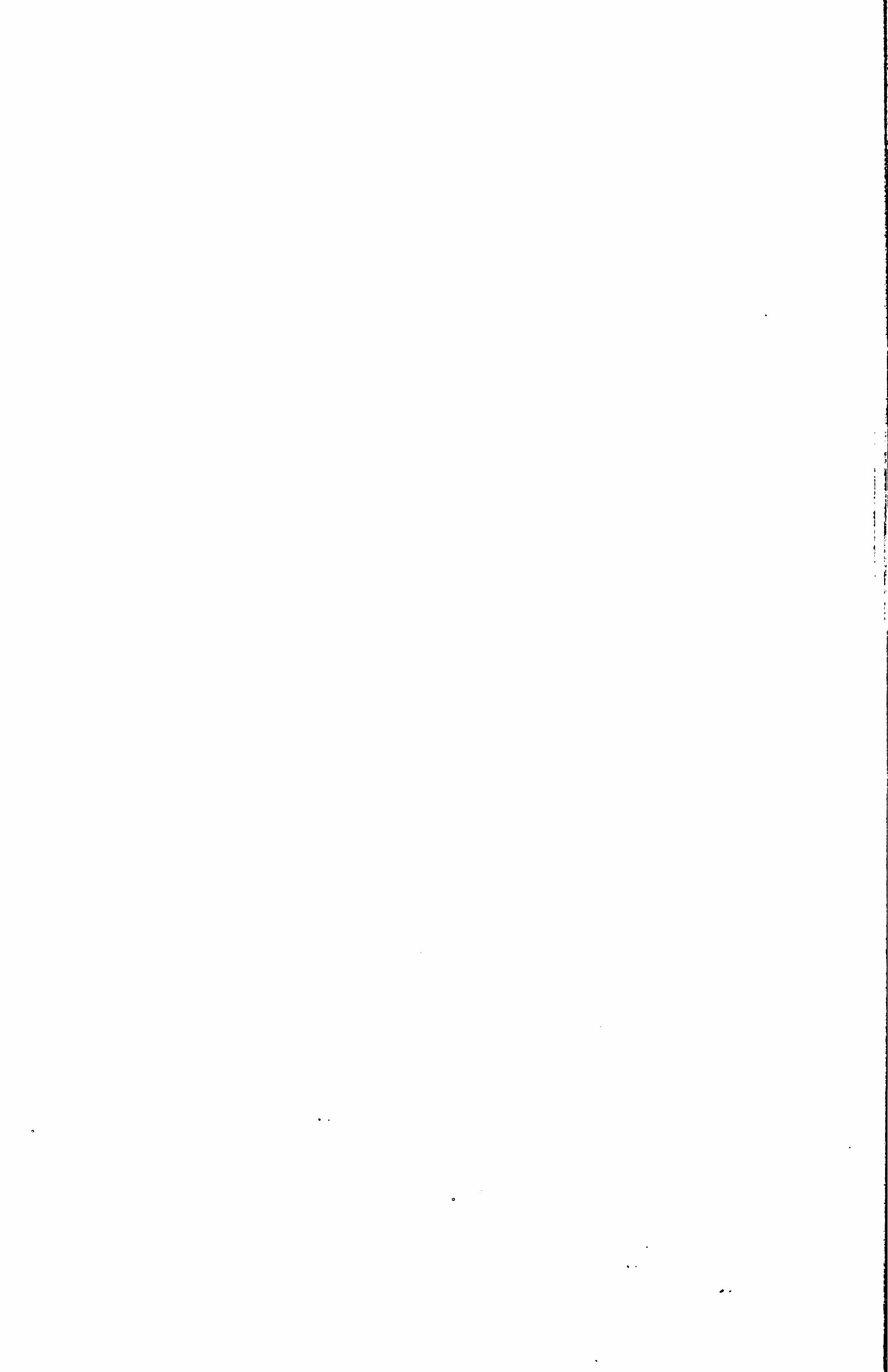